\title{
Contribution of G.A. Ilizarov to bone reconstruction: historical achievements and state of the art
}

\author{
Alexander V. Gubin ${ }^{1}$ - Dmitry Y. Borzunov ${ }^{1} \cdot$ Larisa O. Marchenkova $^{1}$ • \\ Tatiana A. Malkova ${ }^{1}$ - Irina L. Smirnova ${ }^{1}$
}

Received: 16 March 2016/ Accepted: 9 July 2016/Published online: 18 July 2016

(c) The Author(s) 2016. This article is published with open access at Springerlink.com

\begin{abstract}
Methodological solutions of Prof. G.A. Ilizarov are the core stone of the contemporary bone lengthening and reconstruction surgery. They have been acknowledged in the orthopaedic world as one of the greatest contributions to treating bone pathologies. The Ilizarov method of transosseous compression-distraction osteosynthesis has been widely used for managing bone non-union and defects, bone infection, congenital and posttraumatic limb length discrepancies, hand and foot disorders. The optimal conditions for implementing distraction and compression osteogenesis were proven by numerous experimental studies that Prof. G.A. Ilizarov organized and supervised at a large orthopaedic research institute in Kurgan. The tension stress effect on regeneration and growth of tissues was thoroughly investigated with radiographic, histological and biochemical methods. The impact of the Ilizarov method on the progress of bone lengthening and reconstruction surgery could be called revolutionary.
\end{abstract}

Keywords Ilizarov method - Bone regeneration ·

Distraction · Compression · External fixation

\section{Introduction}

Almost 65 years have passed since Prof. G.A. Ilizarov (Fig. 1) introduced his apparatus for external bone fixation and began to develop the techniques for managing bone

Tatiana A. Malkova

tmalkova@mail.ru

1 Russian Ilizarov Scientific Center for Restorative Traumatology and Orthopaedics, 6, M. Ulianova Street, Kurgan, Russian Federation 640014 injuries and orthopaedic diseases [1-7]. Nowadays, his methodological solutions are the core stone of limb lengthening and reconstruction surgery and have been acknowledged in the orthopaedic world as one of the greatest contributions to treating bone pathologies [5-7].

He started to develop his ideas of external fixation in the middle of the last century when he was a rural surgeon in the Kurgan region of Russia. In the 1970-1980s, his ideas grew into a profound fundamental research and clinical work conducted at one of the biggest orthopaedic centres of the world that specializes in bone reconstruction and is his brainchild.

The first Ilizarov external fixator was used for bone fragment fixation to external rings through the wires that transfixed the bone and were able to produce longitudinal compression or distraction in a fractured or osteotomized bone with external threaded rods [7]. The reduction wires (olive wires) and units (hinges) were designed later [1] and provided control of bone fragment positions. Thus, the wires that crossed inside the bone at angles could be guided with the adjustments of the external elements in order to correct bone angulation, translation or torsion. And that was the zest that has resulted in numerous solutions for bone reconstruction with the external apparatus.

\section{Scientific study of distraction osteogenesis}

Prof. G.A. Ilizarov first reported on a positive impact of bone distraction on osteogenesis at the All-Russia Congress of Orthopaedic and Trauma Surgeons in 1963 [8]. Later, bone regeneration in the process of distraction osteogenesis was intensively studied under his guidance by the researchers at a special experimental department of the scientific institute (former name KNIIEKOT); he had 


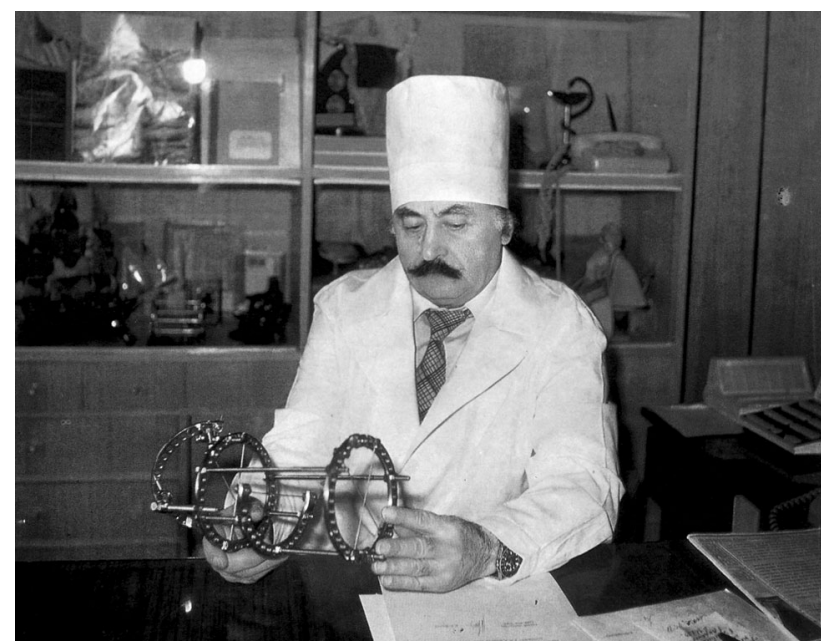

Fig. 1 Prof. G.A. Ilizarov (1921-1992) in his study. Courtesy of the Centre's museum

founded in 1971. Those experiments found optimal conditions for implementing distraction osteogenesis that include stable fixation of bone fragments with the external apparatus, a non-invasive corticotomy, a daily distraction rate of $0.75-1 \mathrm{~mm} /$ day in three or four increments [1-7], limb weight bearing and joint motion that are also an obligatory condition in his treatment system.

The tension stress effect on regeneration and growth of tissues (USSR discovery certificate dated 23.04.1989) that is induced with the forces of the external apparatus was thoroughly investigated with radiographic, histological and biochemical methods [1-6]. Canine experimental models were used to reveal the potential of guided bone distraction on bone tissue growth and the dependence of its quality and quantity on blood supply, rates and rhythm of distraction, the impact of injury to the osteogenic elements of a tubular bone such as bone marrow, endosteum and periosteum, nutrient artery and on bone fragment fixation rigidity. It was proven that the best surgical methods to break the bone and preserve the medullary canal content were corticotomy and closed flexion osteoclasis instead of osteotomies that injure the content [1]. Corticotomy has become a classical way of breaking a bone for lengthening or deformity correction with the Ilizarov apparatus that is produced from a small incision using a chisel to transect the cortex twothirds around the bone and accomplish osteolasis by turning the chisel within the cortex or by counter rotating the rings (Fig. 2).

It was also discovered that along with bone tissue growth other biological tissues of the limb (muscles, nerves, ligaments, tendons and skin) responded to gradual distraction. Gradual distraction induced or supported stimulation of their growth, biosynthetic activity and energy interchange.

It was revealed that the formation of a longitudinal distraction regenerate was accompanied by generation of a large number of vessels of various sizes in the bone itself and in the surrounding tissues. At the end of 1970s, this effect started to be used for stimulation of regional vascularity in ischemic limb diseases by formation of a longitudinal bone split for its transverse traction [9]. Transverse bone distraction was the solution for bone thickening [10] and fibular tibilization in subtotal tibial defects and extensive tibial defects with atrophic tibial fragments when traditional bone plasty is impossible or difficult to realize [11].

Ilizarov transferred his principles to cancellous bone distraction and experimented on dogs to lengthen vertebrae and manage cranial defects. Under his guidance, the techniques for cranial defect (author's certificate from 23.10.83) and spine disorders management with a special apparatus for external fixation of the spine (patented on 06.02.85) started to be developed and later were used at the Centre. Unfortunately, the findings of those experimental studies conducted by him and Centre's researchers were
Fig. 2 A variant of tibial corticotomy which is performed from a $1.5-\mathrm{cm}$ incision on the anteromedial surface. Drilling of the posterolateral cortex with a Kirshner wire is produced tangently to provide a corticotomy direction line

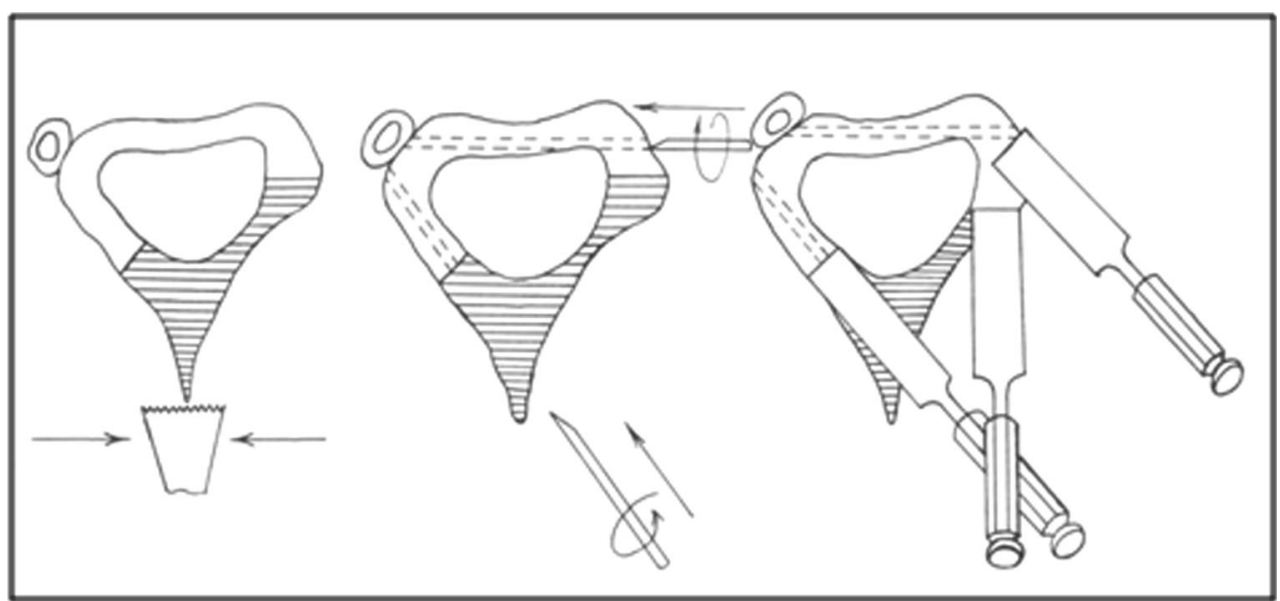


not published in the international journals, but his successors issued a book on craniofacial distraction [12].

\section{Transosseous osteosynthesis}

Ilizarov named his method transosseous compression distraction osteosynthesis and formulated its principles [1, 2]. Worldwide, it is simply called the Ilizarov method though the method is a collective result of a large team of talented scientists, surgeons and engineers, he had gathered around him. It is a system of techniques that induce compression or distraction (or the combination of both forces) by moving bone fragments via transosseous wires with the adjustments of the external ring fixator for bone union, growth or spatial transformation that finally ends in osteosynthesis, consolidation and new bone remodelling. These techniques are named according to the forces applied. The summary of their use for skeletal injuries, their complications, congenital disorders, degenerative diseases and tumours is given in Table 1.

In the Soviet Union, there was (and continues to exist in Russia) a system for certification of inventions and methods by the governmental bodies (former USSR State Committee on Inventions and Discoveries, nowadays Rospatent). The devices invented by Ilizarov were patented, while the techniques developed were certified and published in the USSR Bulletin of Inventions (Table 2). Furthermore, Ilizarov submitted papers on his experimental and clinical studies to the most prominent journals of the Soviet Union such as Ortopedia, Travmatologia y Protezirovanie and Vestnik Khirurgii im. Grekova indexed by the US National Library of Medicine. Therefore, the priority of his techniques can be traced back historically [10, 13-24].

Thanks to the personality of Ilizarov and his strong character, the method overcame the prejudices and became a vivid system that advanced over time. The experimental findings of the scientific school he had created as well as practical techniques were summarized in his famous book that is still the main textbook for those orthopaedic surgeons who start training in the methods of bone lengthening and reconstruction [1]. His concepts served as guidelines for further development of the techniques and devices that have been used nowadays along with the classical Ilizarov method and apparatus [7].

Since the middle of the 1980s, the Ilizarov method has been advancing both technically and conceptually and has spread worldwide. The outcomes of its application in the 1990s and the first decade of the twenty-first century were presented by numerous studies that show the divulgation of the Ilizarov techniques across the globe [25-36]. The reports demonstrated large series of patients and concluded on the value of the Ilizarov techniques, its main disadvantages and complications. Despite good results in the majority of those studies, the authors stressed that the Ilizarov method requires adequate training to master its proper application and reduce the rate of complications [25]. Wire tract infection and a long period with the apparatus on were referred to the main drawbacks of the method. Postoperative monitoring is the key concept and means in the Ilizarov method philosophy that implies a radiographic control of bone fragment position and regeneration quality, adjustments of the frame, soft-tissue care and maintenance of joint motion [7].
Table 1 Compression and distraction techniques

\begin{tabular}{|c|c|c|c|}
\hline \multicolumn{2}{|c|}{$\begin{array}{l}\text { Compression } \\
\text { Longitudinal, side-to-side (or combined) supportive* } \\
\text { unifocal, bifocal (multifocal) }\end{array}$} & \multicolumn{2}{|c|}{$\begin{array}{l}\text { Distraction } \\
\text { Longitudinal, transverse } \\
\text { Unifocal, bifocal (multifocal) }\end{array}$} \\
\hline \multirow{3}{*}{\multicolumn{2}{|c|}{$\begin{array}{l}\text { Fractures } \\
\text { Non-union (congruent bone ends) } \\
\text { Arthrodesis }\end{array}$}} & \multirow{3}{*}{\multicolumn{2}{|c|}{$\begin{array}{l}\text { Bone lengthening (LLD, achondroplasia) } \\
\text { Bone thickening } \\
\text { Deformity correction } \\
\text { stiff non-union }\end{array}$}} \\
\hline & & & \\
\hline & & & \\
\hline \multicolumn{4}{|c|}{ Combined compression-distraction or distraction-compression } \\
\hline \multicolumn{2}{|l|}{ Unifocal } & \multicolumn{2}{|c|}{ Bifocal (multifocal) } \\
\hline Simultaneous & Sequential & Simultaneous & Sequential \\
\hline $\begin{array}{l}\text { Stiff hypertrophic non-union } \\
\text { with angulation (LLD** up to } \\
1 \mathrm{~cm} \text { ) }\end{array}$ & $\begin{array}{l}\text { Stiff hypertrophic non- } \\
\text { union + LLD knee } \\
\text { lengthening arthrodesis }\end{array}$ & $\begin{array}{l}\text { Non-union and } \\
\text { defects + LLD }\end{array}$ & $\begin{array}{l}\text { Non-union } \\
\text { defects (bone } \\
\text { transport) }\end{array}$ \\
\hline
\end{tabular}

* Supportive compression is used every 7-10 days in managing non-union and bone defect

** LLD limb length discrepancy 
Table 2 Certification of the Ilizarov techniques by the USSR certification board and publications in the indexed journals

\begin{tabular}{|c|c|c|}
\hline & Certification of the method & Publication of clinical studies \\
\hline Long bone fracture union and pseudarthrosis (including complicated by infection) & $\begin{array}{l}\text { Applied on } 09.06 .52 \\
\text { Published on 17.08.1954 }\end{array}$ & November 1972 [13] \\
\hline Long bone defects (including complicated by osteomyelitis) (bone transport) & $\begin{array}{l}07.01 .1967 \\
\text { Published on } 07.09 .1971\end{array}$ & $\begin{array}{l}\text { September } 1969[14,15] \\
\text { November } 1973\end{array}$ \\
\hline Hip arthrodesis, femur lengthening & $\begin{array}{l}\text { Applied on } 07.01 .67 \\
05.10 .1971\end{array}$ & June 1969, May $1973[16,17]$ \\
\hline Congenital pseudoarthrosis of the tibia & $\mathrm{n} / \mathrm{a}$ & February, 1969 [18] \\
\hline Long bone lengthening & $\begin{array}{l}\text { Applied on 21.03.1971 } \\
\text { Published on 05.10.1974 }\end{array}$ & March, 1969 [19] \\
\hline Long bone deformity correction & $\begin{array}{l}\text { Applied on } 04.09 .72 \\
\text { Published on 05.07.1975 }\end{array}$ & March 1969 [19] \\
\hline Long bone thickening & $\begin{array}{l}\text { Applied on } 26.03 .74 \\
\text { Published on } 25.09 .1975\end{array}$ & November 1979 [10] \\
\hline Ankle joint arthrodesis & $\mathrm{n} / \mathrm{a}$ & November 1976 [20] \\
\hline Clubfoot & $\begin{array}{l}\text { Applied on } 26.03 .74 \\
\text { Published on } 25.09 .1975\end{array}$ & May 1983 [21] \\
\hline Foot deformity correction and lengthening & $\begin{array}{l}\text { Applied on } 12.04 .76 \\
\text { Published on } 25.09 .1975\end{array}$ & November 1983 [22] \\
\hline Hip disorders & $\begin{array}{l}\text { Applied on } 25.12 .72 \\
\text { Published on } 25.06 .1978\end{array}$ & $1982[23]$ \\
\hline Comminuted fractures & $\begin{array}{l}\text { Applied on } 03.10 .73 \\
\text { Published on } 05.05 .1978\end{array}$ & January $1983[24]$ \\
\hline
\end{tabular}

\section{Ilizarov method in the contemporary orthopaedic practice}

A search of the most recent literature in the NLM PubMed database aids to distinguish the main topics in using the Ilizarov method, and its modifications discussed by the orthopaedic community in all the orthopaedic fields where the Ilizarov method is most applicable.

\section{Complications due to bone injuries or consequences of their management}

The Ilizarov's ideas of external fixation appeared when he had to treat bone non-union or delayed unions in the veterans of World War II. Bone non-union and defects remains the main field where the Ilizarov method has gained undisputable honour [5-7]. He is the author of the bone fragment transport technique that was first described in 1969 [14, 15]. Nowadays, it has become a vital method for compensation of bone defects greater than $4 \mathrm{~cm} \mathrm{[37].}$ Multifocal bone transport for extensive long bone defects was studied experimentally by Ilizarov's disciples, and the techniques of its use were presented for international readers $[11,38]$.

\section{Defects following bone tumour resection}

Bone transport has been lately explored as an option of reconstruction after resection of benign and even malignant bone tumours [39]. This technique is very much relevant in the tibia where the Ilizarov fixator is surgeon and patient friendly [40].

\section{Bone infection}

The Ilizarov method found solutions for one of the most difficult orthopaedic complications-osteomyelitis of any location in posttraumatic and postsurgical cases. Radical debridement, a special protocol of antibacterial therapy, and the antibactericidal effect that develops in tissues due to tension stress in the apparatus [41] are the conditions that enable to fight infection successfully and to reconstruct the affected bone with compression-distraction techniques. Current evidence suggests that the Ilizarov method has established itself as a gold standard for long bone infected non-union and defects [42-44]. A systemic analysis of 24 studies published on the management of infected nonunion of the tibia and femur with the Ilizarov method found that the average rate of bone union was $97.26 \%$ 
and infectious recurrence was $5 \%$ [44]. Periprosthetic infection in total hip replacement that results in extensive removal of necrotic tissue has prompted the search for solution to salvage limbs. The Ilizarov apparatus could be used for this challenging situation. The modified technique of resection arthroplasty was developed at the Centre and showed promising results both in fighting infection and limb salvage [45].

\section{Bone lengthening and deformity correction}

Despite that bone lengthening attempts had been made before the era of Ilizarov [5], bone lengthening tactics and the phenomena that undergo during this procedure were another great achievement of Prof. Ilizarov and his school researchers. The basic idea of lengthening is reproduction of the natural growth provided by the conditions of distraction under the tension stress effect that induce bone cell differentiation, expansion and morphogenesis [46]. A special automated device was invented and patented (23.09.81) that is able to produce high-frequency distraction to bring bone lengthening closer to the natural bone growth. According to research at the Centre, the regenerate formation was superior if the distraction rate of $1 \mathrm{~mm} /$ day was divided into smaller more frequent lengthening steps (60 daily steps of $0.017 \mathrm{~mm}$ each) $[7,34]$. The idea resulted in several generations of automated distractors, and the use of automated lengthening was successfully reported [7, 34]. Automatic high-frequency lengthening with the Ilizarov method provided optimal conditions for faster bone tissue regeneration and a shorter treatment period. Unfortunately, automated external devices have been used in a limited number of cases due to their high costs and possible mechanical failures [47].

Ilizarov rejected intramedullary interference as he relied on the osteogenic potential of bone marrow [1]. However, the contemporary development of the lengthening methods has been subjected to the objective realities such as expenditures of the hospitals and incompliance of patients to wear an external fixator for a long time. A number of motorized intramedullary fully implantable systems have been used that follow the Ilizarov principles of distraction [48]. Such devices reduce or prevent muscle fixation and, therefore, may ease rehabilitation and increase patient comfort.

Another option is the combination of intramedullary nails or flexible hydroxyapatite (HA) coated wires with an external fixator that has been used for regenerated bone reinforcement, reduction of complication rate and duration of hospitalization [49-51]. The surgeons of the Centre introduced HA-coated intramedullary wires instead of a nail for these purposes [51]. A couple of such wires (diameter from 1.5 to $2.0 \mathrm{~mm}$ ) is introduced from the medial and lateral sides at the metaphyseal long bone level and then pushed to the opposite metaphysis in such a way that the ray of their opposite curvature is about $40^{\circ}-50^{\circ}$. The wires do not compromise the bone marrow content and can be easily taken out. It was proven both experimentally and clinically that such wires stimulate new endosteal bone formation and provide mechanical reinforcement and a faster period of treatment $[34,51]$.

During the last 10 years of the twentieth century, a revolution occurred in the management of bone deformities [35]. Ilizarov introduced the techniques of gradual deformity correction via postoperative adjustability of the external fixation. Deformity correction reinforced with flexible intramedullary HA-coated wires allows for considerable reduction of external fixation duration, decrease in the number of complications, and elimination of recurrent deformities in X-linked hereditary hypophosphatemic rickets [52]. The understanding of bone and soft-tissue regeneration has lead to a number of devices and techniques for managing simple or complex deformities, among which the Taylor spatial frame, being a computerized system, has gained a wide use [7, 34, 53].

\section{Rare orthopaedic conditions}

The Ilizarov method showed higher union rates in treating congenital pseudarthrosis of the tibia $[28,54]$. Though the united bone is of an inferior biological and mechanical quality and the refracture rates are high, the method provides a complex approach to deformity correction, lengthening and consolidation in more than a half of patients and can be considered a salvage procedure for this severe condition [54-56]. Reconstructive surgeries including centralization of the knee-ankle joint and lengthening with the Ilizarov principles have been used for such rare disorders as tibial or fibular hemimelia with satisfactory results to salvage the limb $[57,58]$.

\section{Joint arthrodesis}

Despite its difficulties and the need for specific training, the Ilizarov techniques of arthrodesis provide a reliable way of achieving solid fusion with the desired angle. Advantages also include infection control, early mobilization, accurate application and possible conversion to joint replacement in case of hip arthrodesis in young patients [59-61]. Knee joint arthrodesis has shown to be applicable in infected cases after arthroplasty to salvage the limb [61].

As for ankle arthrodesis, there are situations in which a circular external fixator offers significant advantages over screw fixation. The Ilizarov ring system is indicated in difficult cases, especially when additional distal tibial 
pathologic conditions, bone defects, length discrepancies or the need for early weight bearing are present.

\section{Developmental hip disorders}

Hip reconstruction using Ilizarov's concepts is considered technically demanding and involving a lengthy period of wearing the frame. However, it was also found to be a valuable procedure for numerous neglected hip problems particularly in young patients $[62,63]$. By performing the Ilizarov pelvic support osteotomy, the hip could be reserved, the limb length recovered and the gait improved significantly.

\section{Foot and hand pathology}

Prominent contributions were made by Ilizarov to the development of techniques for foot and hand pathology management. Bloodless gradual correction of pediatric clubfoot from the age of 1 year became possible in neglected cases [27]. The Ilizarov techniques for adult multicomponent foot deformities using osteotomies offered versatility in foot position correction, enabling correction of all the components of severe deformities with threedimensional control and lengthening of foot bones [64-66]. Ilizarov and his "hand" team invented a mini-fixator for short tubular bones that has been widely used in the Centre for management of congenital or posttraumatic disorders such as shortened hand bones, finger stumps and syndactyly $[67,68]$.

\section{Fracture repair}

Among the numerous methods of long bone fracture repair, the indications to the use of the Ilizarov method are mostly high energy trauma and paraarticular fractures where open reduction and internal fixation cannot be applied [31-33, 69-72]. Temporary low profile Ilizarov apparatus application has been acknowledged as a safe procedure in cases of severe multiple injuries or polytrauma if applied by experienced surgeons or in particular cases followed by conversion into a specific assembly to address the fractures sustained but once the patient's condition stabilizes.

\section{Contemporary experimental research at the Centre}

A well-known drawback of the Ilizarov method such as a long wear of the apparatus resulted in the search for the ways to stimulate bone regeneration or reinforce the regenerated area. Experimental research in these directions continues and is aimed at finding better mechanical and biological solutions for faster bone formation, remodelling and reduction in treatment time.

A big animal research was dedicated to the study of intramedullary flexible HA-coated wires in bone lengthening and fracture healing which showed promising results as far as they do not compromise the osteogenic potential of bone marrow [73].

Experimental studies on the repair of fractures with different grades of bone marrow trauma showed retardation of osteoreparative processes in cases of bone cavity content removal or its severe damage [74, 75]. A method of mechanical stimulation was found applicable for long bone fracture repair in clinical settings that includes gradual distraction up to $2 \mathrm{~mm}$ in the early postinjury period followed by a 3-day latent period and further acute compression.

\section{Conclusion}

The Ilizarov method has passed a long way of evolution to become an established method in the world orthopaedic practice. The impact of this method on the progress of bone lengthening and reconstruction was called revolutionary [72]. Its principles form the foundation of the contemporary bone lengthening and reconstruction surgery [5].

\section{Compliance with ethical standards}

Conflict of interest The authors declare that they have no conflict of interest.

Statement of human and animal rights This article does not contain any studies with human participansts or animals performed by any of the authors.

Informed consent For this kind of the study, informed consent is not required.

Open Access This article is distributed under the terms of the Creative Commons Attribution 4.0 International License (http://crea tivecommons.org/licenses/by/4.0/), which permits unrestricted use, distribution, and reproduction in any medium, provided you give appropriate credit to the original author(s) and the source, provide a link to the Creative Commons license, and indicate if changes were made.

\section{References}

1. Ilizarov GA (1992) Transosseous osteosynthesis. Theoretical and clinical aspects of the regeneration and growth of tissue. Springer, Berlin

2. Ilizarov GA (1971) Basic principles of transosseous compression and distraction osteosynthesis. Ortop Travmatol Protez 32(11):7-15

3. Ilizarov GA (1989) The tension-stress effect on the genesis and growth of tissues: part I. The influence of stability of fixation and sort tissue preservation. Clin Orthop 238:249-281 
4. Ilizarov GA (1989) The tension-stress effect on the genesis and growth of tissues: part II. The influence of the rate and frequency of distraction. Clin Orthop 239:263-285

5. Jordan CJ, Goldstein RY, McLaurin TM, Grant A (2013) The evolution of the Ilizarov technique. Part 1: the history of limb lengthening. Bull Hosp Jt Dis 71(1):89-95

6. Goldstein RY, Jordan CJ, McLaurin TM, Grant A (2013) The evolution of the Ilizarov technique. Part 2: the principles of distraction osteosynthesis. Bull Hosp Jt Dis 71(1):96-103

7. Gubin AV, Borzunov DY, Malkova TA (2013) The Ilizarov paradigm: thirty years with the Ilizarov method, current concerns and future research. Int Orthop 37(8):1533-1539

8. Ilizarov GA (1963) Our experience of osteosynthesis with the author's apparatus. In: Abstracts of the All-Russia Congress of Trauma and Orthopaedic surgeons, Moscow, pp 166-168 (in Russian)

9. Shevtsov VI, Shurova EN, Shurov VA (1997) Functional outcomes of legs obliterative endarteritis treatment by Ilizarov's method. Khirurgiia (Mosk) 6:47-50 (in Russian)

10. Ilizarov GA, Kaplunov AG, Shevtsov VI, Trokhova VG, Shatokhin VD (1979) Methods of modeling of the leg form and its elongation. Ortop Travmatol Protez 11:28-32

11. Borzunov DY, Chevardin AV (2013) Ilizarov non-free bone plasty for extensive tibial defects. Int Orthop 37(4):709-714

12. Shevtsov VI, Diachkov AN, Khudiaev AT (2001) Substitution of cranial defects by bone transport. In: Samchukov ML, Cope JB, Cherkashin AM (Eds) Craniofacial distraction osteogenesis. Mosby, Elsevier, pp 547-560

13. Ilizarov GA, Kaplunov AG, Degtiarev VE, Lediaev VI (1972) Treatment of pseudarthroses and ununited fractures, complicated by purulent infection, by the method of compression-distraction osteosynthesis. Ortop Travmatol Protez 33(11):10-14

14. Ilizarov GA, Lediaev VI (1969) Replacement of defects of long tubular bones by means of one of their fragments. Vestn Khir Im II Grek 102(6):77-84

15. Ilizarov GA, Lediaev VI, Degtiarev VE (1973) Operative and bloodless methods of repairing defects of the long tubular bones in osteomyelitis. Vestn Khir Im II Grek 110(5):55-59

16. Ilizarov GA, Smelyshev NN (1972) Lengthening of the femur with simultaneous closed arthrodesis of the hip joint. Ortop Travmatol Protez 33(9):62-68

17. Ilizarov GA, Trokhova VG (1973) Surgical lengthening of the femur. Ortop Travmatol Protez 34(11):51-55

18. Ilizarov GA, Gracheva VI (1971) Bloodless treatment of congenital pseudarthrosis of the crus with simultaneous elimination of shortening using dosed distraction. Ortop Travmatol Protez 32(2):42-46

19. Ilizarov GA, Deviatov AA (1969) Surgical lengthening of the shin with simultaneous correction of deformities. Ortop Travmatol Protez 3:32-37

20. Ilizarov GA, Okulov GV (1976) Compression arthrodesis of the ankle joint and adjacent foot joints. Ortop Travmatol Protez 11:54-57

21. Ilizarov GA, Shevtsov VI, Kuz'min NV (1983) Method of treating talipes equinocavus. Ortop Travmatol Protez 5:46-48

22. Ilizarov GA, Shevtsov VI, Kaliakina VI, Okulov GV (1983) Methods of shaping and lengthening the foot. Ortop Travmatol Protez 11:49-51

23. Ilizarov GA, Shved SI (1982) Treatment of unilateral fracturedislocations and isolated femoral dislocations by transosseous osteosynthesis. Sov Med 7:101-102

24. Ilizarov GA, Shved SI, Shigarev VM, Storozhenko SN (1983) Transosseous osteosynthesis in the treatment of multiple and combined injuries. Ortop Travmatol Protez 1:1-4

25. García-Cimbrelo E, Olsen B, Ruiz-Yagüe M, Fernandez-Baíllo N, Munuera-Martínez L (1992) Ilizarov technique. Results and difficulties. Clin Orthop Relat Res 283:116-123
26. Karger C, Guille JT, Bowen JR (1993) Lengthening of congenital lower limb deficiencies. Clin Orthop Relat Res 291:236-245

27. de la Huerta F (1994) Correction of the neglected clubfoot by the Ilizarov method. Clin Orthop Relat Res 301:89-93

28. Damsin JP, Ghanem I, Carlioz H (1996) Contribution of Ilizarov's equipment in the treatment of congenital pseudarthrosis of the lower limb. Rev Chir Orthop Reparatrice Appar Mot 82(1):34-41

29. Maffulli N, Lombari C, Matarazzo L, Nele U, Pagnotta G, Fixsen JA (1996) A review of 240 patients undergoing distraction osteogenesis for congenital post-traumatic or postinfective lower limb length discrepancy. J Am Coll Surg 182(5):394-402

30. Shtarker H, David R, Stolero J, Grimberg B, Soudry M (1997) Treatment of open tibial fractures with primary suture and Ilizarov fixation. Clin Orthop Relat Res 335:268-274

31. Atesalp AS, Basbozkurt M, Erler E, Sehirlioğlu A, Tunay S, Solakoğlu C, Gür E (1998) Treatment of tibial bone defects with the Ilizarov circular external fixator in high-velocity gunshot wounds. Int Orthop 22(6):343-347

32. Pavolini B, Maritato M, Turelli L, D'Arienzo M (2000) The Ilizarov fixator in trauma: a 10 -year experience. J Orthop Sci 5(2):108-113

33. Kumar A, Whittle AP (2000) Treatment of complex (Schatzker Type VI) fractures of the tibial plateau with circular wire external fixation: retrospective case review. J Orthop Trauma 14(5):339-344

34. Shevtsov V, Popkov A, Popkov D, Prévot J (2001) Reduction of the period of treatment for leg lengthening. Technique and advantages. Rev Chir Orthop Reparatrice Appar Mot 87(3):248-256

35. Paley D (2000) Correction of limb deformities in the 21st century. J Pediatr Orthop 20(3):279-281

36. Scher DM, Jeong GK, Grant AD, Lehman WB, Feldman DS (2001) Hip arthrodesis in adolescents using external fixation. J Pediatr Orthop 21(2):194-197

37. Grubor P, Milicevic S, Grubor M, Meccariello L (2015) Treatment of bone defects in war wounds: retrospective study. Med Arch 69(4):260-264

38. Borzunov DY (2012) Long bone reconstruction using multilevel lengthening of bone defect fragments. Int Orthop 36(8):1695-1700. doi:10.1007/s00264-012-1562-1

39. Demiralp B, Ege T, Kose O, Yurttas Y, Basbozkurt M (2014) Reconstruction of intercalary bone defects following bone tumour resection with segmental bone transport using an Ilizarov circular external fixator. J Orthop Sci 19(6):1004-1011

40. Borzunov DY, Balaev PI, Subramanyam KN (2015) Reconstruction by bone transport after resection of benign tumours of tibia: a retrospective study of 38 patients. Indian J Orthop 49(5):516-522. doi:10.4103/0019-5413.164042

41. Paevskiy SA (1992) Method to determine bactericidal activity of tissues. Author certificate priority 1781610 (USSR) \# 4875467/14. Bulletin Inventions, vol 46

42. Yu P, Zhang Q, Mao Z, Li T, Zhang L, Tang P (2014) The treatment of infected tibial nonunion by bone transport using the Ilizarov external fixator and a systematic review of infected tibial nonunion treated by Ilizarov methods. Acta Orthop Belg 80(3):426-435

43. Khan MS, Rashid H, Umer M, Qadir I, Hafeez K, Iqbal A (2015) Salvage of infected non-union of the tibia with an Ilizarov ring fixator. J Orthop Surg (Hong Kong) 23(1):52-55

44. Yin P, Ji Q, Li T, Li J, Li Z, Liu J, Wang G, Wang S, Zhang L, Mao Z, Tang P (2015) A systematic review and meta-analysis of Ilizarov methods in the treatment of infected nonunion of tibia and femur. PLoS ONE 10(11):e0141973. doi:10.1371/journal. pone. 0141973 
45. Kliushin NM, Ababkov YV, Ermakov AM, Malkova TA (2016) Modified Girdlestone arthroplasty and hip arthrodesis using the Ilizarov external fixator as a salvage method in the management of severely infected total hip replacement. J Indian Orthop 1:16-24

46. Ilizarov GA, Palienko LA, Pereslytskikh PF, Galanova RI, Tolmacheva SV (1980) Participation of bone marrow stromal precursor cells and bone regeneration during transosseous osteosynthesis. Bull Eksp Biol Med 89(4):489-490

47. Bright AS, Herzenberg JE, Paley D, Weiner I, Burghardt RD (2014) Preliminary experience with motorized distraction for tibial lengthening. Strateg Trauma Limb Reconstr 9(2):97-100

48. Schiedel FM, Vogt B, Tretow HL, Schuhknecht B, Gosheger G, Horter MJ, Rödl R (2014) How precise is the PRECICE compared to the ISKD in intramedullary limb lengthening? Reliability and safety in 26 procedures. Acta Orthop 85(3):293-298

49. Bukva B, Vrgoč G, Rakovac I, Dučić S, Sindik J, Čoklo M, Marinović M, Bakota B (2015) Complications in leg lengthening using an Ilizarov external fixator and intramedullary alignment in children: comparative study during a fourteen-year period. Injury. doi:10.1016/j.injury.2015.10.058

50. Guo Q, Zhang T, Zheng Y, Feng S, Ma X, Zhao F (2012) Tibial lengthening over an intramedullary nail in patients with short stature or leg-length discrepancy: a comparative study. Int Orthop 36(1):179-184

51. Popkov D, Popkov A, Haumont T, Journeau P, Lascombes P (2010) Flexible intramedullary nail use in limb lengthening. J Pediatr Orthop 30(8):910-918

52. Popkov A, Aranovich A, Popkov D (2015) Results of deformity correction in children with X-linked hereditary hypophosphatemic rickets by external fixation or combined technique. Int Orthop 39(12):2423-2431. doi:10.1007/s00264-015-2814-7

53. Alexis F, Herzenberg JE, Nelson SC (2015) Deformity correction in Haiti with the Taylor Spatial Frame. Orthop Clin N Am 46(1):9-19. doi:10.1016/j.ocl.2014.09.014

54. Borzunov DY, Chevardin AY, Mitrofanov AI (2015) Management of congenital pseudarthrosis of the tibia with the Ilizarov method in a paediatric population: influence of aetiological factors. Int Orthop 40(2):331-339

55. Zhu GH, Mei HB, He RG, Liu K, Tang J, Wu JY (2015) Effect of distraction osteogenesis in patient with tibial shortening after initial union of congenital pseudarthrosis of the tibia (CPT): a preliminary study. BMC Musculoskelet Dis 16:216. doi:10.1186/ s12891-015-0680-5

56. Vanderstappen J, Lammens J, Berger P, Laumen A (2015) Ilizarov bone transport as a treatment of congenital pseudarthrosis of the tibia: a long-term follow-up study. J Child Orthop 9(4):319-324. doi:10.1007/s11832-015-0675-7

57. Balcı Hİ, Sağlam Y, Bilgili F, Şen C, Kocaoğlu M, Eralp L (2015) Preliminary report on amputation versus reconstruction in treatment of tibial hemimelia. Acta Orthop Traumatol Turc 49(6):627-633. doi:10.3944/AOTT.2015.15.0005

58. Popkov A, Aranovich A, Popkov D (2015) Prevention of recurrence of tibia and ankle deformities after bone lengthening in children with type II fibular hemimelia. Int Orthop 39(7):1365-1370. doi:10.1007/s00264-015-2752-4

59. Rabinovich RV, Haleem AM, Rozbruch SR (2015) Complex ankle arthrodesis: review of the literature. World J Orthop 6(8):602-613. doi:10.5312/wjo.v6.i8.602

60. Huang L, Wang S, Teng X, Yang S, Xia Z, Zhao G, Wang T, Wang M (2015) Tibiotalar or tibiocalcaneal arthrodesis using the ilizarov technique in the presence of infected nonunions of ankle joints. Zhonghua Wai Ke Za Zhi 53(6):405-409

61. Kuchinad R, Fourman MS, Fragomen AT, Rozbruch SR (2014) Knee arthrodesis as limb salvage for complex failures of total knee arthroplasty. J Arthroplasty 29(11):2150-2155. doi:10.1016/ j.arth.2014.06.021

62. Mahran MA, Elgebeily MA, Ghaly NA, Thakeb MF, Hefny HM (2011) Pelvic support osteotomy by Ilizarov's concept: is it a valuable option in managing neglected hip problems inadolescents and young adults? Strateg Trauma Limb Reconstr 6(1):13-20. doi:10.1007/s11751-011-0104-5

63. Zang J, Zhang H (2015) Nonarthroplasty methods for developmental dysplasia of the hip with complete dislocation at the age of 8-25 patients. Zhonghua Wai Ke Za Zhi 53(6):472-475

64. Gupta P, Bither N (2014) Ilizarov in relapsed clubfoot: a necessary evil? J Pediatr Orthop B 22(6):589-594. doi:10.1097/BPB. 0b013e32836486de

65. Ganger R, Radler C, Handlbauer A, Grill F (2012) External fixation in clubfoot treatment-a review of the literature. J Pediatr Orthop B 21(1):52-58

66. Kirienko A, Peccati A, Abdellatif I, Elbatrawy Y, Mostaf ZM, Necci V (2011) Correction of poliomyelitis foot deformities with Ilizarov method. Strateg Trauma Limb Reconstr 6(3):107-120. doi:10.1007/s11751-011-0111-6

67. Shevtsov VI, Danilkin MY (2008) Application of external fixation for management of hand syndactyly. Int Orthop 32(4):535-539

68. Danilkin MY (2016) Phalangeal lengthening techniques for brachydactily and posttraumatic digital stumps with the use of a modified external mini-fixator. Tech Hand Up Extrem Surg 20(2):61-66. doi:10.1097/BTH.0000000000000116

69. Keightley AJ, Nawaz SZ, Jacob JT, Unnithan A, Elliott DS, Khaleel A (2015) Ilizarov management of Schatzker IV to VI fractures of the tibial plateau: 105 fractures at a mean follow-up of 7.8 years. Bone Joint J 97-B(12):1693-1697

70. El-Mowafi H, El-Hawary A, Kandil Y (2015) The management of tibial pilon fractures with the Ilizarov fixator: the role of ankle arthroscopy. Foot (Edinb). doi:10.1016/j.foot.2015.08.004

71. Rodriguez-Collazo ER, Urso ML (2015) Combined use of the Ilizarov method, concentrated bone marrow aspirate (cBMA), and platelet-rich plasma (PRP) to expedite healing of bimalleolar fractures. Strateg Trauma Limb Reconstr 10(3):161-166

72. Ostojic N, Kozarski J, Košuti M, Djordjevic B (2014) Treatment of complex war wounds of the lower leg with free flaps and Ilizarov method-our experience. J Reconstr Microsurg 30:A081. doi:10.1055/s-0034-1373983

73. Popkov AV, Kononovich NA, Gorbach EN, Tverdokhlebov SI, Irianov YM, Popkov DA (2014) Bone healing by using Ilizarov external fixation combined with flexible intramedullary nailing versus Ilizarov external fixation alone in the repair of tibial shaft fractures: experimental study. Sci World J 2014:239791. doi:10. $1155 / 2014 / 239791$

74. Stogov MV, Kononovich NA, Nakoskin AN (2008) The details of osteoreparative processes for healing experimental fractures with different degree of bone marrow traumatization. Genij Ortop 2:26-31. http://ilizarov-journal.com/index.php/go/article/view/ $1386 / 1385$

75. Kononovich NA (2006) Reparative regeneration of experimental fractures under osteogenesis mechanical stimulation (an experimental study). Genij Ortop 3:110-115. http://ilizarov-journal. com/index.php/go/article/view/1233/1232 